\title{
Linguagem, pulsão e atavismo: análise genética e mapeamento conceitual em torno do problema do inconsciente em Nietzsche e sua relação com o transcendental ${ }^{*}$
}

\author{
Language, Drive and Atavism: Genetic Analysis and Conceptual \\ Mapping around the Problem of the Unconscious in Nietzsche and \\ its Relation to the Transcendental
}

\author{
William Mattioli \\ william.mattioli@gmail.com \\ (Universidade Federal Fluminense, Niterói, Rio de Janeiro)
}

\begin{abstract}
Resumo: 0 objetivo do presente trabalho é esboçar uma análise do desenvolvimento da noção de inconsciente em momentos importantes do pensamento de Nietzsche. Nosso argumento geral gira em torno de duas hipóteses com as quais pretendemos apresentar uma leitura que vai na contramão da visão comum segundo a qual Nietzsche pertenceria à tradição irracionalista do inconsciente, que tem Schopenhauer como seu mais emblemático representante. Tratase 1) de uma hipótese histórica, que pretende inserir Nietzsche na tradição do inconsciente cognitivo a partir da noção de "representação inconsciente", e 2) de uma hipótese genéticosistemática, que pretende esboçar um plano de compreensão no tocante ao desenvolvimento da concepção nietzscheana do inconsciente, distinguindo e mapeando algumas noções ao longo de sua produção intelectual.
\end{abstract}

Palavras-chave: inconsciente; pulsão; linguagem; atavismo; a priori.
Abstract: The aim of the present paper is to sketch an analysis of the development of Nietzsche's notion of the unconscious in important moments of his thought. Our general argument revolves around two hypotheses with which we intend to present a reading that runs counter to the common view that Nietzsche belongs to the irrationalist tradition of the unconscious, which has Schopenhauer as its most emblematic representative: (1) a historical hypothesis that intends to insert Nietzsche into the tradition of the cognitive unconscious based on the notion of "unconscious representation"; and (2) a genetic-systematic hypothesis, which intends to sketch a plan of understanding vis-à-vis the development of his conception of the unconscious, distinguishing and mapping some notions throughout his intellectual production.

Keywords: unconscious; drive; language; atavism; a priori.

DOI: http://dx.doi.org/10.11606/issn.2318-9800.v22i1p71-98

Entre os poucos consensos existentes na literatura secundária sobre Nietzsche está o entendimento de que o inconsciente tem um papel importante em sua filosofia e aparece como uma noção chave no interior de algumas de suas principais teorias

* Este trabalho foi elaborado durante período de pós-doutorado junto ao Departamento de Filosofia da Universidade Federal Fluminense, com financiamento da CAPES. 
e hipóteses. Uma compreensão satisfatória do lugar que esta noção ocupa em sua obra, do contexto de sua gênese, assim como das leituras que influenciaram sua formulação, do conteúdo teórico que ela carrega ao longo do desenvolvimento de seu pensamento e das transformações pelas quais ela passa nos diferentes períodos de sua produção intelectual, contudo, ainda não faz parte do legado crítico dessa literatura. É comum que sua noção de inconsciente seja vista, sobretudo pela ótica de uma possível antecipação da psicanálise, como derivada de sua herança schopenhaueriana e de seu suposto pertencimento à mesma tradição de seu primeiro mentor intelectual. Trata-se da tradição comumente chamada de irracionalismo, que teria como uma de suas pedras de toque a noção de um inconsciente irracionalpulsional como núcleo do entendimento que temos do homem. Em seu aclamado livro Traditionslinien des Unbewußten. Schopenhauer - Nietzsche - Freud, publicado pela primeira vez em 1999 e que recebeu uma segunda edição reelaborada e ampliada em 2009, Günter Gödde argumenta que é a essa tradição irracionalista do inconsciente, inaugurada por Schopenhauer com sua famosa tese do primado da vontade sobre o intelecto e da radical oposição entre vontade e representação, que pertencem tanto Nietzsche quanto Freud. Diferentemente da tradição representacionalista de Kant e Leibniz, por exemplo, na qual teria se desenvolvido a noção de um "inconsciente cognitivo", a tradição irracionalista, mais notadamente em sua versão schopenhaueriana, teria como um de seus pressupostos básicos o caráter essencialmente não-cognitivo (irracional) do âmbito pulsional. Que isso seja verdade no caso da metafísica da vontade de Schopenhauer não há dúvida, pelo menos de acordo com a autocompreensão de seu autor. Contudo, não nos parece que esse seja o caso no que diz respeito a Nietzsche. ${ }^{1} \mathrm{~A}$ nosso ver, sua noção de inconsciente

1 Para uma crítica semelhante à leitura que Gödde faz da concepção nietzscheana do inconsciente, da qual surgiu boa parte da inspiração para a formulação do problema tal como o apresentamos aqui, cf. Lopes, 2012. Com relação a Freud, a questão talvez seja mais complicada, uma vez que Schopenhauer é um dos poucos filósofos verdadeiramente respeitados pelo psicanalista e em quem ele reconhece explicitamente um antecessor de sua teoria do inconsciente, sugerindo que a vontade schopenhaueriana equivale às pulsões da psicanálise (Uma dificuldade da psicanálise, GW XII, p.12). Mas essa afirmação de Freud não parece de todo correta, mesmo que entre o voluntarismo de Schopenhauer e a psicanálise haja profundos pontos de contato. Para os propósitos deste breve e talvez incauto comentário, me limitarei a esboçar rapidamente dois argumentos não muito elaborados. Além da diferença básica no que diz respeito ao escopo e ao alcance de cada um dos modelos (uma vez que a vontade de Schopenhauer é um princípio cosmológico-metafísico, ao passo que a pulsão freudiana, pelo menos a princípio, se reduz a um elemento psicológico-biológico interno a uma concepção clínica e científica), há ainda uma distinção importante relativa aos aspectos estruturais e à definição da dinâmica própria a cada uma dessas instâncias. Se a vontade schopenhaueriana é absolutamente destituída de qualquer componente intencional, de qualquer predicado relativo à representação, o inconsciente freudiano, por outro lado, como argumenta Sebastian Gardner (1999, p.381), é marcado por intencionalidade; e é essa intencionalidade que determina o inconsciente enquanto complexo de estados motivacionais. As pulsões que constituem o inconsciente se definem pelo seu direcionamento a um objeto, pela sua relação com as representações que the concedem um conteúdo qualitativo. Esse direcionamento intencional do conteúdo do inconsciente, por mais primitivo ou distante daquele dos desejos conscientes, é o que o distingue de estados puramente somáticos. Mesmo que Freud busque caracterizar o inconsciente em termos "econômicos", a partir 
Linguagem, pulsão e atavismo: análise genética e mapeamento conceitual ...

é muito mais complexa do que sugere a inserção apressada de seu pensamento na tradição do irracionalismo schopenhaueriano.

0 argumento geral do presente trabalho ${ }^{2}$ gira em torno de duas hipóteses com as quais pretendemos apresentar uma leitura que vai na contramão da interpretação aludida acima. Trata-se I) de uma hipótese histórica, que pretende inserir Nietzsche na tradição do inconsciente cognitivo a partir da noção de "representação inconsciente", e II) de uma hipótese genético-sistemática, que pretende esboçar um plano de compreensão no tocante ao desenvolvimento da concepção nietzscheana do inconsciente, distinguindo e mapeando algumas noções ao longo de sua produção intelectual. A título de curiosidade, como alusão a uma possível abordagem comparativa e sistemática, eventuais paralelos com a psicanálise serão indicados em notas de rodapé.

II.

$\mathrm{Na}$ introdução à sua obra principal, Filosofia do inconsciente, Eduard von Hartmann introduz o leitor no campo de suas investigações através de uma citação de Kant (Hartmann 1869, p.1). O fato de Kant ser o filósofo invocado aqui como ponto de partida de uma análise do inconsciente pode, à primeira vista, provocar um certo espanto naqueles familiarizados com a filosofia da autoconsciência na qual se baseia a primeira Crítica. A citação apresentada por Hartmann como frase de abertura de sua obra principal é, entretanto, retirada da Antropologia:

de um vocabulário quantitativo, isso em nada muda na compreensão de sua intencionalidade, pois, de fato, todo tipo de fenômeno psicológico pode, a partir dessa abordagem, ser caracterizado nos termos de uma "energia psíquica" quantitativamente analisável. Não parece restar dúvidas, por sua vez, que o modo como Freud apresenta seu modelo metapsicológico pressupõe uma escolha de princípio pelo vocabulário intencional em detrimento do vocabulário energético / quantitativo. Isso se mostra de forma mais clara, sobretudo, no texto $O$ inconsciente. A escolha por esse vocabulário mentalista é o que, em última instância, traz inteligibilidade aos fenômenos abordados, razão pela qual ele deve ter prioridade explicativa. Com efeito, uma das razões essenciais que conduziram Freud à asserção da existência do inconsciente é o fato de que os dados da consciência se mostram profundamente lacunares, de modo que frequentemente nos deparamos com "atos psíquicos que pressupõem, para sua explicação, outros atos de que a consciência não dá testemunho" ( $O$ inconsciente, GW X, p.265). Para Carlos Drawin, essa formulação da função teórica atribuída ao inconsciente aproxima o modelo metapsicológico de um modelo transcendental do psiquismo. $\mathrm{E}$ isso porque o inconsciente, apesar de ser uma "realidade metapsicológica que não é acessível, em si mesma, à introspecção, (...) se impõe como a condição que torna possível a compreensão da observação introspectiva de nossa própria vida interior" (Drawin 2005, p.492). Ora, a inteligibilidade daqueles outros atos psíquicos aos quais Freud se refere e dos quais a consciência não dá testemunho só pode estar assegurada se formos capazes de remetê-los cognitivamente a associações psíquicas que nos são de certo modo palpáveis, isto é, a mecanismos intencionais compreensíveis a partir da perspectiva de primeira pessoa, mesmo que estes nos pareçam à primeira vista inteiramente idiossincráticos.

2 No trabalho que se segue, desenvolvo de forma mais detalhada e procuro corrigir alguns argumentos apresentados no texto: "Das Unbewusste als transzendentaler Raum perspektivistischer Weltbildung bei Nietzsche" (Mattioli 2012). Trata-se, assim, de uma versão em português, consideravelmente reelaborada e expandida deste texto. 
Ter representações $e$, contudo, não estar conscientes delas, aí parece haver uma contradição, pois, como podemos saber que as temos se delas não estamos conscientes? Essa objeção já foi feita por Locke, o qual por isso mesmo também rejeitou a existência de semelhante espécie de representações. - No entanto, podemos ser mediatamente conscientes de ter uma representação, mesmo que não sejamos imediatamente conscientes dela (Anthropologie... AA VII, p.135).

Apesar da referência a Locke ser deixada de lado no texto de Hartmann, ela é de grande importância para o escopo do presente trabalho, como pretendemos mostrar. Hartmann afirma então que essas palavras do grande pensador de Königsberg contém o ponto de partida de suas próprias investigações. Que se trata aqui da retomada, por Kant, da problemática das representações inconscientes ou obscuras, introduzida por Leibniz e desenvolvida em seguida por seus sucessores, fica claro através da sequência do texto kantiano, onde a divisão leibniziana em representações obscuras, claras e distintas é apresentada. O próprio Hartmann invoca a herança leibniziana da problemática do inconsciente e reconhece que a leitura de Leibniz foi o que primeiramente o estimulou em direção às análises desenvolvidas em sua obra principal.

Em que pese a importância de se chamar atenção para o fato de que os termos "representação inconsciente" (unbewusste Vorstellung) ou "representação obscura" (dunkle Vorstellung) não ocorrem sistematicamente nos textos de Leibniz, esta questão não desempenha nenhum papel fundamental na elaboração do nosso problema. É verdade que os termos utilizados por Leibniz são, antes, petites perceptions ou perceptions sans apperception, e isso num contexto no qual a metáfora da luminosidade assume um papel importante: as perceptions sans aperception serão consideradas, nesse contexto, como percepções obscuras. Estes conceitos, porém, serão traduzidos, no desenvolvimento da problemática em questão, por "representações inconscientes" ou "obscuras" (unbewusste ou dunkle Vorstellungen), ${ }^{3}$ e à metáfora da luz e da luminosidade somar-se-á ainda a metáfora da profundeza; o lugar próprio das representações obscuras será então o fundus animae, a profundeza da alma (der Grund der Seele). ${ }^{4}$

Na esteira dessa tradição, Kant escreve nos Prolegomenos: “O meu lugar é o fértil Bathos da experiência, e a palavra transcendental (...) não significa algo que ultrapassa toda a experiência, mas sim o que a precede ( $a$ priori), sem com isso estar determinado a outro fim que o de simplesmente tornar possível o conhecimento pela experiência” (Prolegomena, AA IV, p.373). O termo Bathos (em grego: profundeza) é colocado em oposição à dimensão das alturas, com a qual, segundo Kant, os

3 Para uma discussão acerca da tradição aqui referida, cf. Grau 1916, pp.196ss., Grau 1922, pp.18ss., Adler 1988, Nicholls e Liebscher 2010, pp.4ss.

4 Esta é a designação dada por Baumgarten ao complexo de percepções ou representações obscuras na alma (cf. Grau 1916, p.200, Adler 1988, Nicholls e Liebscher 2010, p.9). 
metafísicos estariam implicados. O campo semântico que o termo Bathos compreende é, nesse sentido, o mesmo dos adjetivos "profundo" (tief), "obscuro" (dunkel), assim como das expressões "fundus animae" e "Grund der Seele" (profundeza da alma). No Kant-Lexikon de Rudolf Eisler (1961, p.56), o termo Bathos é definido como: Niederung der Erfahrung (chão baixo, fundamento, profundeza da experiência). Outras expressões que aparecem em Kant em diferentes lugares, mas que se inserem num mesmo contexto, são por exemplo: “niedriger Boden der Erfahrung” (chão baixo da experiência) (AA II, p.368), "tiefer Abgrund der menschlichen Erkenntnis" (abismo profundo do conhecimento humano) (AA XXVIII, p.227), "dunkler Raum des Verstandes" (espaço obscuro do entendimento) (AA XVIII, p.93). ${ }^{5}$ Todas essas expressões apontam para o caráter inconsciente de certas atividades intelectuais que são ao mesmo tempo constitutivas para o pensamento consciente. Para Kant, há uma série de operações do entendimento que são executadas fora do alcance da luz da consciência e que funcionam como condição para a objetividade da experiência. ${ }^{6} \mathrm{De}$ forma análoga a Leibniz, para quem as representações obscuras e a cognitio obscura a elas associada constituem o fundamento do conhecimento claro e consciente e funcionam como uma forma de pré-condição para o mesmo (Adler 1988, p.199), Kant vê no campo das representações obscuras "um tesouro que constitui o abismo profundo do conhecimento humano, o qual não podemos alcançar" (AA XXVIII, p.227, apud. Satura 1971, pp.54s.). Diferentemente de Leibniz e da tradição de seus sucessores, porém, Kant não qualifica esse campo de representações obscuras atribuindo-lhe uma potencialidade cognitiva menor ou reduzida. Para ele, ao contrário, existem operações plenas do entendimento, ou seja, atividades cognitivas complexas, que nosso espírito executa fora do alcance da luz da consciência. Dessa forma, tornase claro que essas reflexões sobre o inconsciente, realizadas em grande parte no contexto da psicologia do conhecimento ou da antropologia, são de fundamental importância também para a filosofia transcendental enquanto tal. ${ }^{7}$ Uma vez que se admite que "a maior parte das atividades do entendimento ocorre na obscuridade" (AA XV, p.65), uma filosofia que delas se ocupe não pode permanecer alheia a esse caráter inconsciente dos processos cognitivos. Ao associar, nos Prolegomenos, 0 conceito de “Bathos der Erfahrung” à noção de transcendental, Kant faz alusão à conexão fundamental que há entre atividades inconscientes do espírito e condições transcendentais da experiência. ${ }^{8}$

\footnotetext{
5 Essas passagens me foram apresentadas pela primeira vez num curso oferecido em Toulouse pelo professor Mário Jorge Pereira de Almeida Carvalho, da Universidade de Lisboa, em 2010, em torno da noção kantiana de "Bathos der Erfahrung", em que elas foram discutidas tendo em vista sua importância para o tema do inconsciente em Kant.

6 Cf. a esse respeito La Rocca 2008, Rohden 2009, Souza e Brito 2015, p.306.

7 Sobre a importância da noção de representação inconsciente na primeira crítica, ver La Rocca 2008, pp.461ss., Rohden 2009.

8 Essa leitura se torna ainda mais fecunda se estivermos dispostos a interpretar o sujeito da
} 
Aqui repousa, na verdade, o ponto central da controvérsia entre empiristas e racionalistas com relação à origem das representações. Se partirmos da tese segundo a qual pensamento e consciência coincidem, ou seja, que a alma somente pensa na medida em que tem consciência, o que corresponde basicamente às concepções tanto de Descartes como de Locke, segue-se daí que não pode haver nenhuma atividade inconsciente do entendimento; assim, a existência de algo como representações inconscientes deve ser negada. Nada pode estar presente no espírito sem estar ao mesmo tempo presente à consciência. A recusa de Locke com relação à existência de ideias inatas está essencialmente associada à sua recusa de conteúdos inconscientes do espírito. Ora, a existência de ideias inatas só pode ser aceita de forma consequente se aceitamos ao mesmo tempo que estas são, em princípio, inconscientes. Isto fica claro no caso de uma criança que já é capaz de falar, identificar objetos no mundo, referir-se predicativamente a esses objetos, construir sentenças judicativas, mas não é capaz de explicitar ou de prestar contas acerca de sua utilização das funções gramaticais e dos conceitos de sujeito, predicado e objeto, assim como acerca dos fundamentos e razões do próprio juízo. Ou seja, a criança não é consciente das formas lógicas e sintáticas que regem seus processos cognitivos e, portanto, não é capaz de representá-las conscientemente para si (cf. Satura 1971, p.62).

Nesse sentido, a resposta de Locke à pergunta acerca da origem das representações presentes no espírito é, a partir da perspectiva de uma tradição racionalista ou crítica, insuficiente ou insatisfatória, na medida em que o recurso aos princípios de associação, determinados a posteriori através da percepção, não é capaz de explicar a forma lógica do juízo, a estrutura sintática do pensamento em geral e

apercepção transcendental (do "eu penso") como uma forma de subjetividade inconsciente. A apercepção transcendental, enquanto unidade última de todas as sínteses cognitivas, não é uma consciência de si no sentido de algo acessível à introspecção. Antes pelo contrário, trata-se de uma unidade formal, destituída de qualquer conteúdo intuitivo. Como argumentam Gardner (1999, p.388) e Kemp Smith (2003, p.179), as sínteses transcendentais não são conscientes em nenhum sentido ordinário ou factual, uma vez que elas nem estão presentes à consciência (sendo, antes, sua condição de possibilidade), nem podem ser ali presentificadas; somente seus produtos são conteúdos conscientes. Nesse sentido, o "eu penso", que "deve poder acompanhar todas as minhas representações" (CRP, B 132), não se refere a um fato psicológico, mas sim a uma possibilidade estrutural. $O$ fato psicológico de que uma representação é acompanhada pela consciência do seu pertencimento ao eu é definido por Kant como "consciência empírica" (La Rocca 2008, p.462). Mas "a consciência empírica que acompanha diferentes representações é em si mesma dispersa e sem referência à identidade do sujeito" (CRP, B 133). Essa identidade pertence, antes, à estrutura unitária da apercepção transcendental. Carlos Drawin (2005, p.414), numa linha de argumentação que se aproxima de algumas hipóteses de leitura sugeridas por Gardner (1999, p.389), oferece uma interpretação bastante produtiva dessa condição ambivalente do sujeito transcendental, ao associá-lo ao inconsciente freudiano, tal como este é pensado no modelo metapsicológico, sugerindo que a metapsicologia poderia oferecer uma resposta aos impasses kantianos de conceitualização daquele "eu penso". Ao interpretá-lo como inconsciente e conceder-lhe assim um certo nível de objetividade e de concretude (de que sua função meramente formal no argumento kantiano o havia destituído), o modelo freudiano instauraria um outro nível de inteligibilidade com relação ao "eu penso", reinserindo-o na história e restituindo-lhe o caráter de uma intencionalidade dinâmica. A nosso ver, algo próximo a isso pode ser encontrado em Nietzsche. 
as regras categoriais que estão em sua base, quando não as pressupõe tacitamente. A semântica empirista, de caráter atomístico, é insuficiente para explicar a estrutura lógica e sistemática segundo a qual nossos conceitos se organizam em formas predicativas determinadas. Assim, é preciso que haja no espírito princípios a priori, apesar de inconscientes, sobre cuja base a articulação de conteúdos perceptivos se tornaria então possível e que esclareceriam de forma satisfatória a estruturação lógica do pensamento.

III.

No aforismo 20 de Além do bem e do mal, Nietzsche pretende apresentar sua tese do condicionamento do pensamento, especialmente do pensamento filosófico, através de funções gramaticais inconscientes. Segundo ele, os filósofos descrevem, "à mercê de um encanto invisível” e "graças ao domínio e direção inconsciente das mesmas funções gramaticais", sempre a mesma órbita. Dessa forma, eles preenchem sempre um certo esquema básico de filosofias possíveis, o que significa que seu pensamento, apesar do seu sentimento de independência e de sua vontade crítica ou sistemática, é sempre condicionado inconscientemente pelas estruturas da linguagem. Nietzsche encerra então o aforismo com a seguinte frase, que é recebida pelo leitor não sem uma certa surpresa: "Isso como resposta à superficialidade de Locke no tocante à origem das ideias" (ABM 20).

O fechamento do aforismo obriga o leitor relativamente surpreso a uma releitura do texto, de forma que a crítica a Locke e ao mesmo tempo o alcance e a natureza da tese de Nietzsche aparecem numa luz mais clara. Uma vez contextualizado, isto é, uma vez referido à controvérsia entre os defensores de uma concepção empirista da mente como tabula rasa e os defensores de alguma forma de inatismo, o aforismo concede uma inteligibilidade maior a algumas expressões nele presentes, como por exemplo: "sistemática inata dos conceitos" ou "filosofar é um atavismo de primeira ordem". O que Nietzsche chama aqui de atavismo é sua versão deflacionada do inatismo. Trata-se de uma crítica à tese empirista, de cunho sensualista, acerca da origem dos conceitos (ou ao menos de certos conceitos). Para o filósofo, conceitos basilares da filosofia, como "sujeito", “substância”, “objeto”, “causalidade”, não são derivados da experiência e, nesse sentido, não são representações isoladas, abstraídas individualmente de conteúdos perceptivos determinados. Essas representações remetem a estruturas cognitivas pertencentes a uma herança atávica que nos é comunicada principalmente através da estrutura de afetos e impulsos e através da estrutura da linguagem (Lopes 2006, p.188). Assim, elas se encontram numa relação de dependência umas com as outras, são conceitos que "crescem em relação e em parentesco um com o outro", pertencendo a "um sistema, assim como 
os membros da fauna de uma região terrestre". Lanier Anderson, em um primoroso comentário sobre este aforismo, argumenta que, segundo a tese defendida ali, "o conteúdo de nossos conceitos fundamentais é determinado holisticamente" (Anderson 2002, p.100). Se tivéssemos que dar razão a Locke, assumindo que todo conceito é abstraído de uma experiência particular, então cada um deles seria separado dos outros, derivado da sensibilidade por uma via de abstração própria e independente. Contra esse atomismo semântico, Nietzsche mobiliza a tese de que certos conceitos estão organizados numa cadeia lógica definida, que corresponde àquela "inata e sistemática afinidade" existente entre eles. As representações inconscientes das quais falávamos anteriormente são, aqui, as estruturas sintáticas da linguagem, formas herdadas por cada indivíduo em virtude de seu pertencimento à espécie humana, a uma tradição e, consequentemente, a uma rede simbólica específica no interior de uma determinada cultura. ${ }^{9}$

IV.

Podemos dizer que o germe desta tese já estava presente no jovem Nietzsche, apesar de aparecer ali sobre o pano de fundo de uma concepção da natureza de cunho mais romântico e sob influência da Filosofia do inconsciente de Hartmann. As primeiras reflexões do jovem filólogo acerca da linguagem remontam ao texto concebido como introdução ao curso de gramática latina oferecido na universidade de Basel entre 1869 e 1870, intitulado "Da origem da linguagem" (Vom Ursprung der Sprache) (KGW II 2, pp.185-188). O segundo parágrafo do texto é aquele que contém talvez as observações mais importantes no que diz respeito ao escopo de nossa análise:

Todo pensamento consciente só é possível com ajuda da linguagem. É inteiramente impossível um pensamento tão perspicaz com algo como uma linguagem sonora meramente animal: o prodigioso organismo, dotado de um sentido profundo. Os mais profundos conhecimentos filosóficos já se encontram preparados na linguagem. Kant diz: "uma grande parte, talvez a maior parte da ocupação da razão consiste no desmembramento dos conceitos que ele [o espírito humano] já encontra em si mesmo". Pensemos no sujeito e no objeto. O conceito de juízo é abstraído da proposição gramatical. Do sujeito e do predicado foram extraídas as categorias de substância e acidente (KGW II 2, p.185).

Esse trecho representa um recorte de passagens retiradas do capítulo VI da Filosofia do inconsciente de Hartmann, intitulado "O inconsciente na origem da linguagem” (Hartmann 1869, pp.227ss.). Ali se encontram, colocadas lado a lado, a

\footnotetext{
9 É possível que haja aqui paralelos interessantes com a teoria lacaniana de um inconsciente estruturado como linguagem. Não sendo capaz de desenvolver de maneira adequada essa suposição, remeto o leitor aos comentários de Stack (1983, pp.187ss.) e Crawford (1988, p.135 e p.137), que veem nessa concepção nietzscheana um tipo de estruturalismo avant la lettre.
} 
tese de que a linguagem não é o produto de uma atividade reflexiva conscientemente elaborada, uma vez que ela é condição de possibilidade do próprio pensamento, e a tese de que os conceitos fundamentais da filosofia, enquanto pedras angulares do pensamento, já se encontram articulados na sintaxe inconsciente da linguagem. Há aqui um enfoque claro no aspecto formal predominante em todas as línguas, enquanto fundamento cognitivo comum, em detrimento de sua diversidade cultural. Nesse sentido, a argumentação de Hartmann procura tornar plausível a tese de que a estrutura gramatical inconsciente constitui a base para a formação da reflexão consciente e condiciona geneticamente toda especulação filosófica, na medida em que oferece à reflexão um conjunto de formas e noções pré-determinadas (Crawford 1988, pp.34s.). Esse “tesouro de especulação inconsciente" (Hartmann 1869, p.228) identificado na linguagem, do qual são destacados os conceitos gramaticais de sujeito e predicado, é o correlato das categorias kantianas do entendimento na versão do transcendentalismo traduzida nos termos da ciência linguística da época. A menção a Kant, cuja introdução à Crítica da razão pura é citada com uma pequena modificação, ${ }^{10}$ ilustra muito bem a pretensão de retraduzir o elemento central do argumento transcendental para o registro de uma ambicionada filosofia crítica da linguagem. ${ }^{11}$ Essa versão cientificamente esclarecida do argumento transcendental apresentada por Hartmann foi recebida com simpatia pelo jovem Nietzsche. Ele parece ter reconhecido nela uma teoria capaz de lidar de modo historicamente consistente com o problema da origem da linguagem sem precisar reduzi-la à origem puramente sensível, uma vez que ela lança mão da ideia de uma estrutura inconsciente. Seu recorte resumido das principais teses de Hartmann nos dá uma boa indicação de como ele está pensando a noção de inconsciente nesse momento. Trata-se da noção de um inconsciente cognitivo, linguisticamete estruturado e de natureza essencialmente sintática.

Nesse contexto, o reconhecimento da existência de representações inconscientes, responsáveis pela articulação sintática da cognição, é talvez um dos pontos nodais da trama que liga Hartmann e Nietzsche a Kant e que os situa, mesmo que de um modo um tanto quanto tortuoso, na mesma tradição do inconsciente, que não é a do irracionalismo de Schopenhauer. Trata-se, antes, da tradição do

10 No original kantiano, lemos: "uma grande parte, talvez a maior parte da ocupação da razão consiste no desmembramento dos conceitos que já temos de objetos" (CRP, B 32). Hartmann modificou a citação provavelmente com vistas a acentuar o fato de que os conceitos que temos de objetos só são possíveis a partir da determinação inconsciente das estruturas sintáticas que já se encontram pré-formadas no espírito humano.

11 Cavalcanti (2005, p.49) afirma, a meu ver acertadamente, que "o objetivo de Hartmann é enfatizar, a partir da citação de Kant, a tarefa da filosofia como um 'trazer à consciência' da estrutura unitária de conceitos subjacentes à linguagem, desvelando, desse modo, a unidade das categorias constitutivas do pensamento".. 
inconsciente cognitivo. ${ }^{12}$

Se partirmos da afirmação do jovem Nietzsche de que "os mais profundos conhecimentos filosóficos já se encontram preparados na linguagem" (KGW II 2, p.185), e somarmos a isso a tese, tomada igualmente de Hartmann, de que a linguagem se constitui a partir de estruturas sintáticas inconscientes, não é sem alguma surpresa que descobrimos em Kant as seguintes passagens: "uma grande parte dos pensamentos filosóficos já está preparada na obscuridade” (AAXXV, p.479); e "todos os conhecimentos racionais (...) são preparados na obscuridade" (AA XV, p.665). ${ }^{13}$ Como vimos, os termos "obscuro" e "obscuridade" (dunkel, im Dunklen) constituem um campo semântico importante das reflexões sobre as representações inconscientes na tradição cognitiva de Leibniz e Kant. A ideia de que uma grande parte dos conteúdos cognitivos que constituem nossos conhecimentos já se encontra preparada numa dimensão inconsciente do espírito parece atravessar o racionalismo moderno como sua contraface necessária (Satura 1971, p.52). A homenagem prestada por Hartmann a Kant na introdução à sua obra magna está, portanto, perfeitamente no lugar.

Tendo como pano de fundo esse transcendentalismo heterogêneo de Hartmann, o que veríamos no primeiro momento do pensamento de Nietzsche sobre a linguagem seria, portanto, a noção de um inconsciente linguístico de natureza sintático-estrutural, que condicionaria nosso pensamento consciente e nossas funções cognitivas em geral através de funções gramaticais.

Não podemos deixar de notar aqui, porém, que Nietzsche, seguindo a argumentação da Hartmann, reconduz a linguagem a uma origem instintiva,

12 Segundo Gödde (2009), tanto Hartmann quanto Nietzsche pertenceriam à tradição irracionalista emblematicamente representada por Schopenhauer. Como mencionado anteriormente, a esta tradição Gödde contrapõe, além da tradição vitalista, a tradição cognitiva, representacionalista, de Kant e Leibniz. A nosso ver, porém, nem Hartmann nem Nietzsche se deixam enquadrar sem problemas naquela tradição irracionalista. Na filosofia do inconsciente de Hartmann, o inconsciente é caracterizado "como atividade sintética-formadora, em analogia com os atos humanos orientados racionalmente a um fim" (Brinkmann 1943, p.48). Isso fica claro em sua crítica a Schopenhauer. Ao relegar a representação à esfera secundária da consciência animal como produto de uma estrutura fisiológica (cerebral), Schopenhauer teria ignorado a existência de representações inconscientes e, com isso, teria cometido um erro grave ao ignorar que "a vontade inconsciente pressupõe, eo ipso, uma representação inconsciente como fim, objeto e conteúdo de si mesma" (Hartmann 1869, p.18). A isso se soma a concepção schopenhaueriana segundo a qual todos os conceitos são representações de segundo grau, isto é, derivadas por abstração das intuições sensíveis (o que corresponde essencialmente à tese sensualista de Locke). Por sua vez, mesmo que Hartmann não reconheça na tradição de Kant e Leibniz um conceito robusto de inconsciente - uma vez que, nessa tradição, o inconsciente estaria associado a representações com intensidade infinitamente baixa e, portanto, a um grau infinitamente pequeno de consciência -, ele atribui a estes autores o mérito de ter introduzido a noção de "representação inconsciente", reconhecendo aqui, como vimos, o ponto de partida de suas próprias investigações (Hartmann 1869, p.1 e p.14). Na esteira de Hartmann, Nietzsche compreende os processos inconscientes como processos marcados por componentes cognitivos e assume claramente a tese leibniziana da existência de representações inconscientes (cf. sobretudo GC 357). Falaremos mais sobre esta questão logo à frente.

13 Cf. La Rocca 2008, pp.459s. 
entendendo o instinto não como uma disposição redutível ao mecanismo fisiológico, isto é, como resultado da organização corporal ou cerebral (KGW II 2, p.186), mas como uma instância inconsciente dotada de intencionalidade e marcada por um princípio teleológico, que ele busca compreender a partir de uma leitura (pouco cautelosa, é verdade) da terceira Crítica de Kant. ${ }^{14}$ À pergunta: "como e de onde surge a linguagem?”, ele responde a princípio dizendo como ela não pode ter surgido: "a linguagem não é obra consciente de indivíduos, nem de uma maioria" (KGW II 2 , p.185). Ela seria algo demasiadamente complicado para o trabalho individual e demasiadamente unitária para o trabalho consciente e refletido de um grupo massivo de indivíduos. O caráter orgânico do qual dá testemunho a complexidade de suas formas estruturais (para Nietzsche, a linguagem é um todo orgânico - ein ganzer Organismus) só nos deixa uma opção: entendê-la como produto do instinto e de sua conformidade a fins. Mais à frente, após rejeitar uma série de hipóteses de diferentes pensadores acerca da origem da linguagem, Nietzsche afirma que o verdadeiro conhecimento de tal origem só nos é possível depois de Kant, que, "em sua Crítica da faculdade do juízo, ao mesmo tempo reconheceu a teleologia na natureza como algo efetivamente existente e, por outro lado, salientou a maravilhosa antinomia segundo a qual há algo conforme a fins sem uma consciência. Esta é a essência do instinto" (KGW II 2, p.188).

V.

Poucos anos depois, Nietzsche parece assumir uma abordagem distinta e em certo sentido oposta à abordagem na qual se baseia o texto Sobre a origem da linguagem, na medida em que esta última depende de uma teoria essencialmente sintática da cognição. A nosso ver, essa nova abordagem traz consigo um novo conceito daquilo que pretendemos designar como inconsciente linguístico-cognitivo. A base dessa nova concepção do inconsciente parece ser o modelo tropológico da cognição desenvolvido por ele no contexto das reflexões sobre o conhecimento e sobre a relação entre retórica e linguagem presentes no texto Sobre verdade $e$ mentira no sentido extramoral, de 1873. O conceito fundante desse modelo é o conceito de metáfora. Nietzsche desenvolve esse modelo a partir de uma discussão com a tese das inferências inconscientes, tese em voga na época e que buscava explicar a percepção sensível como uma operação de natureza lógica. ${ }^{15}$ De acordo com esse modelo, a percepção se constitui com base numa operação inconsciente que consiste em inferir, da reação dos órgãos dos sentidos ou do efeito recebido

14 Com exceção do teleologismo explícito, assumido a partir da leitura da Crítica do juízo, as semelhanças com o modo como ele lida com o problema da linguagem nos textos da década de 1880 são significativas, como veremos mais à frente.

15 Ver a esse respeito: Orsucci 1994, Reuter 2004, Reuter 2009 e Mattioli 2010. 
pelos mesmos, a causa da sensação, que é então associada a um objeto no mundo. Ou seja, nossa imagem do mundo sensível se originaria graças a um princípio atuante nos órgãos sensoriais que seria, em última instância, idêntico àquele que rege nossos juízos lógicos. Nessa concepção, os órgãos responsáveis pela construção do mundo fenomênico operam segundo leis fixas e invariáveis, de forma que sua operação é acompanhada de necessidade e universalidade (cf. Helmholtz 1855, p.20).

Ao que tudo indica, este é o aspecto central da tese das inferências inconscientes contra o qual Nietzsche faz valer seu modelo tropológico. Ao afirmar que "são tropos, não inferências inconscientes, sobre os quais repousam nossas percepções sensíveis” (N 1872, 19[217]), ele parece querer ressaltar que necessidade, universalidade e logicidade são características conceituais interconectadas e que pertencem estruturalmente a um nível de abstração que não corresponde à dinâmica contingente dos processos inconscientes que estão na base da cognição. Ele compreende o mecanismo ao qual se refere a tese das inferências inconscientes como um mecanismo de produção de analogias, e hesita em assentir que a formação de uma analogia possa conter a forma de uma dedução lógica (Reuter 2004, p.368). Para o Nietzsche de Verdade e mentira, deduções lógicas pressupõem uma estrutura simbólica específica que pertence àquele columbário conceitual entendido por ele como um produto tardio da formação de metáforas (VM, KSA 1, p.882). É sobre a base destas últimas que se origina a cognição, e elas devem ser descritas, antes, como contingentes, individuais e ilógicas. Segundo ele, isso implica que nós pensamos e vivemos constantemente sob o efeito do ilógico, na medida em que só construímos o mundo fenomênico com base em processos de metaforização que estão aquém de toda lógica. A transposição fisiológica de um estímulo nervoso em imagem, que Nietzsche qualifica através do conceito de metáfora, é a primeira etapa do surgimento da consciência. Nesse sentido, a condição de possibilidade do surgimento da consciência repousaria sobre um inconsciente cognitivo cujas funções, por sua vez, poderiam ser descritas como sendo de natureza puramente semântica.

Este é um dos pontos principais que gostaríamos de destacar na concepção de inconsciente desenvolvida nesse período. De fundamental importância aqui é o fato de que essa concepção, ao contrário da concepção apresentada anteriormente de um inconsciente sintático-estrutural, traz consigo o conceito de um inconsciente linguístico-cognitivo que pretendemos designar como semântico-figurativo. No interior do modelo tropológico do jovem Nietzsche, as imagens que constituem o pensamento inconsciente (uma vez que este se dá puramente em intuições e imagens, e não em conceitos (N 1872, 19[117])) são selecionadas, assimiladas, traduzidas e substituídas sem recurso a um esquema estrutural que oriente essas operações segundo regras fixas, universais ou necessárias. Ou seja, a semântica do pensamento inconsciente não seria, em princípio, regida por nenhuma sintaxe que defina ou 
Linguagem, pulsão e atavismo: análise genética e mapeamento conceitual ...

determine a priori a relação entre estímulo e imagem ou das imagens entre si, de forma que o dinamismo aqui presente seria marcado pelo emblema da contingência. ${ }^{16}$ O problema desse modelo em certa medida atomístico, no qual imagens são assimiladas e substituídas sem que elas estejam submetidas a uma determinada sintaxe ou lógica proposicional, parece não ter permanecido oculto aos olhos do jovem Nietzsche. Ao afirmar, em um fragmento da mesma época, que aquele "pensamento em imagens não é a princípio de natureza rigorosamente lógica, mas ainda assim mais ou menos lógico" (N 1872, 19[107]), Nietzsche parece referir-se à seguinte questão: como seria possível trazer a rede dinâmica de imagens à unidade estrutural e categorial do conceito se nessa rede mesma já não houvesse algum elemento de logicidade que tornasse essa categorização possível?

VI.

Tendo em vista a perspectiva teórica aberta por essa questão, pode-se constatar uma mudança de atitude por parte de Nietzsche, já na segunda metade da década de 1870, frente à pergunta pela natureza dos processos inconscientes que estão na base da cognição. Essa mudança parece ocorrer sobretudo como resultado de sua recepção da obra de Afrikan Spir. ${ }^{17}$ Em alguns textos desse período, sobretudo

16 Nietzsche parece se voltar a essa nova abordagem sobretudo em função da centralidade assumida pelos fenômenos estéticos em suas reflexões, fenômenos que ele busca compreender também a partir de um tipo de "fisiologia da arte" (acredito que não seja descabido utilizar essa expressão em referência aos escritos do jovem Nietzsche, mesmo que ela pertença em especial ao contexto da obra de maturidade). Em consonância com essa posição, há um interesse em entender o próprio conhecimento a partir da ideia (estética) de criação, na qual se encontra implícita uma certa noção de espontaneidade, de abertura à contingência. A nosso ver, uma das motivações centrais de Verdade e mentira é colocar em relevo a força artística inconsciente que está por trás de todos nossos processos cognitivos, designada aqui como "impulso à formação de metáforas". Diferentemente do que ocorre em $O$ nascimento da tragédia, onde essa força é apresentada através do embate e da reconciliação entre os impulsos artísticos apolíneo e dionisíaco (neste caso, com destaque ao impulso apolíneo enquanto força figurativa), a indicação do caráter pervasivo dessa força se dá, neste texto póstumo, a partir de uma reflexão epistemológica sobre a percepção, sua base fisiológica e sua relação com a formação da linguagem. Um dos fios condutores de Nietzsche é a convicção de que a linguagem é expressão de um movimento ao mesmo tempo crítico e estético-transfigurador. É a esse movimento que Nietzsche dá o nome de metáfora, elaborando, a partir daí, seu modelo tropológico da cognição. A metáfora se mostra assim como uma nova forma de se entender aquele lugar de transmutação do conhecimento em arte (Reuter 2009, p.193), apresentado em $O$ nascimento da tragédia a partir da figura do Sócrates musicante. Tendo em vista não ultrapassar os limites e o escopo do presente trabalho, pretendo desenvolver em artigos futuros uma análise mais profunda e detalhada do papel que o inconsciente assume no contexto do Nascimento da tragédia, assim como do modo como essa noção aparece nas diversas camadas das reflexões elaboradas em Verdade e mentira. Esses dois textos são objeto dos capítulos IV e V de minha tese de doutorado: $O$ inconsciente no jovem Nietzsche. Da intencionalidade das formas naturais à vida da linguagem. UFMG: Belo Horizonte, 2016.

17 Spir (1837 - 1890), filósofo de origem russa, mas que escreveu suas obras principais em alemão, foi um neo-kantiano que buscou renovar a filosofia transcendental e recuperar sua especificidade metodológica frente à ameaça que representava a tentativa de naturalização da perspectiva transcendental a partir do materialismo da época (cf. Lopes 2011). Sua releitura da filosofia crítica 
de Humano, demasiado humano ( $\mathrm{HH}$ 18) e dos fragmentos de 1875 (9[1], KSA 8, pp.135s.), Nietzsche defende a tese de que nossas operações cognitivas de base não são puramente semânticas, mas sim de natureza lógico-predicativa. ${ }^{18}$ Elas ocorrem no interior de uma relação lógica entre o princípio de identidade, entendido como lei orgânica do pensamento, e a necessidade subjetiva, inerente a todo ato cognitivo (por mais primitivo que seja), de ordenar a experiência e reconhecer objetos permanentes no mundo empírico. Essa relação lógica corresponderia ao quadro sintático no interior do qual toda experiência se constitui.

Esta concepção é desenvolvida por Nietzsche no que se convencionou chamar de período intermediário de sua produção filosófica até se concretizar na sua crítica à gramática, que ocupa um lugar central de sua obra de maturidade. A crítica de Nietzsche à gramática tem por base a tese de que à nossa crença em substâncias, que assume o papel de categoria de base de configuração da experiência, corresponde o esquema sintático sujeito-predicado, através do qual nós imprimimos no devir o

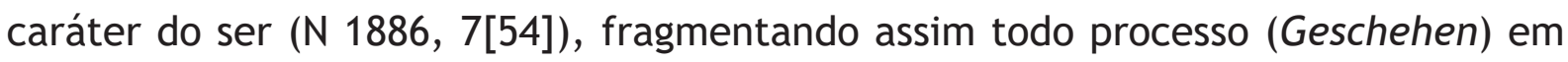
relações causais. 0 que pretendemos apontar nessa tese é a ideia de uma gramática fundamental atuante de forma inconsciente na construção de todo e qualquer conteúdo intencional da consciência. Nesse sentido, esta gramática inconsciente estaria na base de toda experiência de mundo e de toda experiência de si enquanto sujeito. ${ }^{19}$

considera que o único elemento a priori da cognição, no sentido rigorosamente transcendental, é o princípio lógico da identidade. Este seria o elemento fundamental de organização da experiência, do qual depende nossa capacidade de estabelecer e identificar objetos empíricos estáveis, compreendidos como substâncias, a partir dos dados sempre instáveis das sensações. Isso se daria mediante a projeção de uma lógica predicativa na organização das sensações, de modo que impressões diversas são apreendidas, na forma de um juízo sintético, como atributos de substâncias ontologicamente autônomas. Nesse sentido, o princípio de identidade assume a função de discriminante ontológico, e atua não somente como princípio analítico, mas igualmente como princípio sintético. À época de composição dos fragmentos que contrapõem um modelo tropológico da cognição à tese das inferências inconscientes, Nietzsche já havia travado contato com Spir, mas nesse momento ele ainda busca reconduzir a sintaxe judicativa proposta por Spir à semântica das transferências figurativas (metafóricas e metonímicas), como pode ser notado no fragmento 19[242] de 1872 (cf. Mattioli 2013b, pp.329ss.). A partir da segunda metade da década de 70 , porém, em sua releitura de Spir, Nietzsche parece se voltar novamente a uma abordagem da cognição que atribui aos processos cognitivos básicos um caráter sintático e judicativo.

18 Os dois textos indicados fazem referência indireta a Spir. Em HH 18, Spir é o "lógico eminente" de quem Nietzsche toma de empréstimo a frase que serve como ponto de partida da discussão do aforismo (cf. D'lorio 1993, p.274). Já no fragmento 9[1] de 1875, onde Nietzsche se confronta com o problema da relação entre otimismo e pessimismo a partir do livro Der Werth des Lebens, de Eugen Dühring, Spir é o autor por trás da noção de identidade apresentada ali como um princípio constitutivo de nosso entendimento judicativo e avaliativo: "nós trazemos em nós uma medida com a qual medimos a existência e que é inteiramente imutável: trata-se do princípio de identidade. (...) toda inclinação ou aversão já pressupõe o entendimento e nele o princípio de contradição: sem o lógico, não há sensação, disposição ou representação" (KSA 8, p.136s.; cf. sobre isso Riccardi 2009, pp.95s.).

19 Para Nietzsche, a consciência ou o eu consciente, que se apresenta na perspectiva de primeira pessoa como "eu pensante", é de antemão condicionado linguisticamente, como fica claro em 
É a partir dessas reflexões que Nietzsche elabora sua crítica a Locke no aforismo 20 de Além do bem e do mal. Ele rejeita a tese sensualista pois acredita que há uma determinação fundamentalmente inconsciente no modo como se dá nossa aquisição de conceitos como "substância”, “causalidade”, etc. Essa determinação inconsciente é, por sua vez, fruto de uma herança atávica. Em mais de um momento, Nietzsche se refere à linguagem como algo que é herdado pelos homens enquanto membros de uma mesma espécie e de uma mesma comunidade. Nela, o homem tem um tesouro imprescindível para o desenvolvimento da humanidade, na medida em que ela constitui o horizonte fundamental, passado de geração a geração, no interior do qual ele organiza simbolicamente seu mundo e se adapta às condições do seu meio de forma a poder viver em grupo e desenvolver algo como cultura. Com a linguagem e suas funções sintáticas é transmitida ao homem, além disso, a crença básica na verdade de certas estruturas predicativas (N 1886, 4[8]). Essa crença, que está inconscientemente presente em todo juízo, assume a forma de uma faculdade cognitiva em virtude da qual o indivíduo é capaz de reduzir experiências a signos e criar assim um mundo simbólico que é, em última instância, o único mundo humano possível. A possibilidade de formação e construção de mundo se fundaria, nesse sentido, no caráter simbólico e linguístico da existência humana, uma vez que todo ato de pensamento e de apreensão e interpretação de mundo é regido formalmente pela gramática.

$\mathrm{Na}$ medida em que as estruturas de base da linguagem são algo como uma herança de um passado remoto da humanidade, à qual está ligada nossa crença mais antiga, pensar (sobretudo o pensar filosófico) representa então um "atavismo de primeiríssima ordem". Daí a tese de que o pensamento filosófico, "na realidade, não é tanto descoberta quanto reconhecimento, rememoração (Wiedererinnern); retorno a uma primeva, longínqua morada perfeita da alma, de onde os conceitos um dia brotaram" (ABM 20). Aqui, além de considerar o filosofar como uma forma de atavismo, Nietzsche faz ainda uma referência enviesada à teoria platônica da reminiscência (o pensamento como rememoração). Estamos certamente diante de uma formulação impregnada de ironia, mas não destituída de sentido. Não há dúvidas de que, aos olhos de Nietzsche, essa “longínqua morada da alma” não é o mundo inteligível das ideias platônicas, mas algo de outra ordem.

O aforismo 5 do capítulo “A 'razão' na filosofia”, do Crepúsculo dos ídolos, confirma nossas suspeitas e nos dá um bom indicativo do que Nietzsche tem em mente aqui. Ao falar sobre a origem das "categorias da razão", sobretudo da categoria do "Ser", ele afirma, dando expressão à voz dos "filósofos", que elas não

sua crítica ao cogito, já vastamente discutida na literatura secundária (o mais recente estudo monográfico sobre o tema é Loukidelis 2013). Como argumenta Simon (1984, p.32), é somente nas formas determinadas da gramática que ele pode refletir e se representar a si mesmo como identidade. Sobre esse tema, cf. ainda os artigos de Giacoia Jr. (2011) e Itaparica (2011). 
poderiam "proceder do mundo empírico - todo o mundo empírico as contradiz. De onde procedem, então? - E na Índia, como na Grécia, foi cometido o mesmo erro: 'Devemos já ter habitado um mundo mais elevado'”, ao que Nietzsche acrescenta: “em vez de um bem mais baixo: o que teria sido a verdade!" ( $\mathrm{Cl}$, Razão 5) 0 “mundo mais elevado" do qual se fala aqui é uma clara referência à teoria platônica da anamnese, que pressupõe a migração da alma para o reino das ideias, após a morte. Ao rejeitar essa teoria, Nietzsche não contesta, contudo, que haja em nós algo como uma memória arcaica, inata, que condiciona inconscientemente nossa relação cognitiva com o mundo. ${ }^{20} 0$ que é negado é que o princípio que nela habita tenha sua origem num "mundo mais elevado". Trata-se, antes, de um mundo "bem mais baixo".

Se nos perguntarmos agora qual é esse "mundo bem mais baixo", o aforismo 18 de Humano, demasiado humano nos fornecerá uma resposta:

Quando algum dia se escrever a história da gênese do pensamento, nela também se encontrará, sob uma nova luz, a seguinte frase de um lógico eminente: "A lei universal do sujeito cognoscente consiste na necessidade interior de reconhecer cada objeto em si, em sua própria essência, como um objeto idêntico a si mesmo, portanto existente por si mesmo e, no fundo, sempre igual e imutável, em suma, como uma substância". Também essa lei, aí denominada "originária", veio a ser - um dia será mostrado como gradualmente surge essa tendência nos organismos inferiores $(\mathrm{HH}$ $18)$.

A partir desse texto fica claro que, aos olhos de Nietzsche, a origem das "categorias da razão" - e a ênfase recai manifestamente sobre a categoria do "Ser" - remonta às fases mais primitivas da história dos organismos. A "lei universal do sujeito cognoscente” mencionada aqui é, como indicado anteriormente, uma alusão

$20 \mathrm{Um}$ paralelo bastante sugestivo com a teoria freudiana do inconsciente talvez possa ser estabelecido a partir deste ponto, se temos em mente as reflexões de Freud sobre os "esquemas filogeneticamente herdados, que, semelhante às 'categorias' filosóficas, têm o papel de classificar as impressões recebidas na vida". Freud tende a pensar estes esquemas como "sedimentos da história da cultura humana" (História de uma neurose infantil, GW XII, p.155). Tanto Freud quanto Nietzsche partem aqui de um conjunto de teses da biologia evolutiva da época que giram em torno da teoria da recapitulação (sobre isso, ver nota 21 a seguir). Bernard Baas (2001, pp.14s.) aproxima esta teoria freudiana do "esquema filogenético" a um modelo transcendental. Contudo, a depender do sentido que atribuirmos à noção de transcendental nesse contexto, essa aproximação pode se mostrar falsa. Com efeito, tais esquemas herdados remontam a um evento determinado e historicamente localizável no desenvolvimento da espécie. Nesse sentido, eles teriam uma gênese empírica. A não ser que estejamos dispostos a assumir um sentido de transcendental mais próximo daquele presente nas tentativas de naturalização do kantismo da segunda metade do século XIX (Lange, Helmholtz e, com alguma ressalva, Schopenhauer), a determinação empírica daqueles condicionantes psíquicos os distancia do modelo transcendental (agradeço à professora Léa Silveira por ter chamado minha atenção a este ponto particular da determinação empírica do inconsciente freudiano, o que torna problemática qualquer tentativa de aproximá-lo do transcendental kantiano). Para uma interessante discussão da relação entre as teses de Nietzsche sobre o atavismo e a teoria dos arquétipos de Jung (a quem Freud faz alusão em sua discussão da herança filogenética, GW XII, p.131), cf. Bishop 1995, pp.304s. 
Linguagem, pulsão e atavismo: análise genética e mapeamento conceitual ...

à teoria do a priori de Spir. O sistema desenvolvido por Spir com base na filosofia transcendental kantiana busca reconduzir o a priori a um único elemento constitutivo: o princípio de identidade. Segundo ele, é deste princípio transcendental que derivam nossos conceitos de Ser e do Incondicionado, que, por sua vez, funcionam como discriminantes ontológicos responsáveis pela nossa capacidade de fixar e identificar objetos no mundo externo. Ao se apropriar da tese de que nossa relação com o mundo está incontornavelmente condicionada por certas categorias cognitivas, Nietzsche entende este princípio transcendental como uma herança atávica de estágios primitivos da evolução dos organismos, que continua a determinar inconscientemente nossos modos de percepção. ${ }^{21}$

21 Trata-se aqui de um tema caro a Nietzsche, que encontra ressonâncias não só no texto de ABM 20, mas também, entre outros, no belíssimo aforismo 54 de $A$ gaia ciência, onde a tese do atavismo é apresentada na forma de uma epifania existencial ao mesmo tempo reconciliatória e aterrorizante: "Como é nova e maravilhosa e, ao mesmo tempo, horrível e irônica a posição que sinto ocupar, com meu conhecimento, diante de toda a existência! Eu descobri que a velha humanidade e animalidade, e mesmo toda a pré-história e o passado de todo ser que sente, continua inventando, amando, odiando, raciocinando em mim - no meio deste sonho acordei repentinamente, mas apenas para a consciência de que sonho e tenho de prosseguir sonhando, para não sucumbir". Kirchhoff (1977, pp.38ss.) discute com bastante propriedade o problema do atavismo e a noção de anamnese em Nietzsche neste contexto, apontando uma interessante relação entre ABM 20 e GC 54, assim como dois fragmentos de 1885. Os fragmentos são os seguintes: $\mathrm{N}$ 1885, 36[35] (KSA 11, p.565) e N 1885, 2[146] (KSA 12, p.139). No primeiro, que leva em seu título a famosa expressão do "corpo como fio condutor", Nietzsche fala do corpo humano como algo em que "todo o passado mais distante e mais recente de todo o devir orgânico (alles organischen Werdens) se torna mais uma vez vivo e encarnado". No segundo, cujas expressões remetem mais diretamente à noção de anamnese, lemos: "É possível estabelecer uma analogia plena entre as operações de simplificação e condensação de inumeráveis experiências em princípios gerais e a geração do espermatozoide, que traz em si, condensado, todo o passado: e igualmente entre a produção artística a partir de pensamentos básicos gerativos, até o 'sistema', e a gênese do organismo enquanto processo contínuo de concepção, invenção e cognição (Aus- und Fortdenken), enquanto reminiscência (Rückerinnerung) de toda a vida passada, enquanto recapitulação (Rück-Vergegenwärtigung), incorporação." Nessas passagens, a alusão ao tema platônico da reminiscência se dá ao mesmo tempo em que Nietzsche faz eco a uma teoria bastante difundida na biologia da época, de autoria do biólogo e filósofo Ernst Haeckel. Este último foi o maior representante do darwinismo na Alemanha na segunda metade do século XIX, com cujas ideias Nietzsche travou contato desde muito cedo. A teoria em questão é a teoria da recapitulação, ou lei biogenética, segundo a qual a ontogênese (ou desenvolvimento individual) recapitula e abrevia a filogênese, isto é, a história do desenvolvimento da espécie. Num outro importante fragmento de 1885, o fragmento 40[34], Nietzsche estende a tese da recapitulação aos nossos complexos afetivos e cognitivos e a contrapõe explicitamente ao sensualismo de Locke e à sua rejeição das "ideias inatas”. À época de composição de Humano, demasiado humano, Nietzsche estava lendo também a obra Descendenzlehre und Darwinismus, de Oscar Schmidt, que consiste em grande parte numa apresentação das teses de Haeckel, sobretudo da lei biogenética. Algumas passagens importantes de Humano remetem à influência das teses Haeckel e Schmidt, como os aforismos sobre o sonho (HH 12 e 13; cf. Assoun 2000, pp.122s.) e o aforismo sobre os homens cruéis (HH 43; cf. Orsucci 1996, p.54). No que diz respeito ao fragmento 2[146] acima citado, Orsucci (1996, p.54, nota 4) observa que o termo usado por Nietzsche ao se referir à "recapitulação" (Rück-Vergegenwärtigung), retoma a própria terminologia de Schmidt, quando este afirma que "a história do desenvolvimento do indivíduo recapitula (vergegenwärtige) a história da espécie". Essa parece ser a concepção por trás das alusões de Nietzsche à "fisiologia e a história da evolução dos organismos e dos conceitos" ( $\mathrm{HH} 10$ - note-se que ele concebe a história dos conceitos como parte da "história natural"), assim como à "história da gênese do pensamento" (HH 18). Para uma discussão mais abrangente da relação de Nietzsche com a biologia da época de um modo geral, e com Haeckel em particular, ver Frezzatti Jr. 2014, Emden 2014, Moore 2003. 
Já em Humano, demasiado humano, ele vê a linguagem como uma estrutura simbólica que reproduz, em suas formas mais fundamentais, aquele princípio cognitivo primitivo $(\mathrm{HH} 11,19)$. 0 núcleo da tese de um condicionamento inconsciente pelas formas gramaticais como veículo de transmissão de estruturas atávicas, tal como esta é apresentada nos textos da década de 1880, está aqui pré-configurado. 0 aforismo 20 de Além do bem e do mal é, por sua vez, o texto paradigmático no tocante a este ponto. Nos deparamos ali, como vimos, com o conceito de um inconsciente linguístico-cognitivo de natureza sintático-estrutural, que atua em toda interpretação de mundo como sua condição de possibilidade mesma. E isso graças ao fato de que todo pensamento se forma e se desenvolve de antemão e necessariamente no interior de um sistema gramatical que o precede e ao qual, em princípio, ele não tem um acesso epistêmico. Dessa forma, a estrutura da linguagem se encontraria inconscientemente na base de todo tornar-se consciente, ou seja, de toda consciência de mundo e de toda consciência de si.

Que a consciência se encontra numa relação tão estrita com a linguagem que sem a determinação desta última ela jamais seria possível (e tampouco necessária), eis a resposta de Nietzsche à pergunta pelo "para quê?" da consciência, apresentada por ele no aforismo 354 de $A$ gaia ciência na forma de uma "conjectura talvez extravagante". Para ele, essa pergunta adquire seu verdadeiro significado somente em relação à pergunta pelo inconsciente. Com efeito, a vida inteira seria possível sem que ela se visse no espelho. Nietzsche invoca Leibniz, afirmando que foram necessários dois séculos para se alcançar a premonitória suspeita do filósofo, cuja concepção é apresentada no aforismo 357 da mesma obra da seguinte forma: "a consciência é tão somente um accidens da representação, não seu atributo necessário e essencial"; "isso que denominamos consciência constitui apenas um estado de nosso mundo espiritual e psíquico (...) e de modo algum ele próprio". Com essa incomparável percepção, Leibniz teria obtido razão "não só perante Descartes, mas ante tudo aquilo que havia sido feito em filosofia até então" (GC 357).

A referência a Leibniz nesse aforismo remonta ao artigo "Die Metamorphosen des Apriori", do neo-kantiano Otto Liebmann (Loukidelis 2006, p.302s.). Neste texto, Liebmann discute o desenvolvimento da problemática do a priori desde Descartes até Kant e dedica algumas páginas à controvérsia entre Descartes e Locke. $O$ ponto central dessa controvérsia consiste em que tanto Descartes quanto Locke partem do pressuposto de que "ter representações" e "estar conscientes delas" significam a mesma coisa. Porém, Descartes sustenta a existência de ideias inatas, o que para Locke é insustentável, uma vez que estas não estão de forma nenhuma presentes na consciência de uma criança recém-nascida, por exemplo. De acordo com Liebmann, essa controvérsia é parcialmente resolvida pela descoberta de Leibniz do caráter inconsciente da maior parte de nossas representações, e então definitivamente 
solucionada pela tese kantiana acerca das condições transcendentais da experiência (Liebmann 1911, pp.212ss.). O cerne do problema pode ser resumido da seguinte forma, como é apresentado por Vladimir Satura em seu livro sobre a psicologia do conhecimento de Kant (Satura 1971, p.52): se as ideias ou representações devem ser em algum nível inatas, o que, por razões críticas, acreditamos ter que aceitar; e se nós não somos conscientes delas imediatamente após o nascimento, o que a experiência atesta - nesse caso devemos supor que elas se encontram de antemão no espírito, porém em um estado latente, inconsciente, e constituem um mundo particular e próprio que é muito mais vasto que o mundo das representações conscientes.

VII.

No que concerne à concepção nietzscheana do inconsciente, podemos constatar, com base no aforismo 20 de Além do bem e do mal, que o que é expresso na tradição de Leibniz e Kant através da noção de "representações inconscientes" é associado, como vimos, à estrutura gramatical da linguagem. Mas o aforismo contém ainda um segundo movimento argumentativo: Nietzsche reconduz as funções gramaticais atuantes inconscientemente em nossas interpretações de mundo à fisiologia. Esse movimento de recondução da linguagem ao corpo fica claro na última parte do aforismo, de forma que a argumentação do texto sofre aqui, pelo menos aparentemente, um deslocamento de perspectiva. Por um lado, o discurso acerca do condicionamento inconsciente do pensamento através da gramática se move fundamentalmente no interior de uma perspectiva de primeira pessoa. Isso não significa, porém, que ele se dê meramente via introspecção - cuja confiabilidade e eficácia cognitivas são insistentemente contestadas por Nietzsche -, mas sim mediante análise reflexiva da estrutura predicativa de nossas crenças básicas acerca do mundo e de nós mesmos. O recurso à ciência linguística e ao estudo comparativo das línguas oferece um contrapeso empírico ao princípio em certa medida apriorístico da análise, sem, contudo, dissolvê-lo, uma vez que só é possível compreender o que significa para um agente cognitivo ser compelido a apreender o mundo segundo formas linguísticas determinadas a partir da perspectiva do próprio agente cognitivo consciente de si e dotado de linguagem. Nesse sentido, é somente na medida em que esse agente, enquanto dotado de linguagem e diante da experiência concreta do real, examina as categorias substantivas do pensamento e as estruturas intelectuais que condicionam sua percepção do mundo (num movimento reflexivo análogo ao que chamaríamos de exame transcendental), que ele está em condições de afirmar a tese de um condicionamento inconsciente do pensamento por certas formas gramaticais. ${ }^{22}$

22 Quanto a isso, note-se o seguinte: a tese segundo a qual um estado mental só se torna consciente na medida em que é articulado linguística e conceitualmente (GC 354; cf. sobre isso Katsafanas 2005, Riccardi 2015a), assim como a tese de que a experiência que temos de nós próprios como sujeitos 
Por outro lado, porém, a recondução das funções gramaticais à fisiologia, tal como esta se dá ao final do aforismo, depende, em princípio, de uma perspectiva de terceira pessoa. Trata-se aqui de um importante momento do pensamento nietzscheano comumente associado ao naturalismo. Essa perspectiva de terceira pessoa diz respeito à investigação que toma o corpo como fio condutor, investigação prezada por Nietzsche como o ponto de partida essencial do filosofar. Nietzsche acredita que através de uma investigação do corpo nós obtemos uma noção mais rica da unidade complexa que reina no nosso organismo e frente à qual a unidade gramaticalmente condicionada da consciência não passa de uma função. A essa complexa organização corporal nós não temos acesso a partir da perspectiva de primeira pessoa, isto é,

depende de uma estrutura sintática determinada (ABM 16, 17 e 54), só parecem fazer sentido no interior da perspectiva de primeira pessoa. E isso porque o vocabulário próprio à perspectiva de terceira pessoa é avesso aos termos básicos em torno dos quais Nietzsche articula essas teses, que se referem, antes de mais nada, à fenomenologia do nosso mundo interior. Note-se ainda que é justamente o conjunto de ideias subjacente a estas teses que sustenta diversas afirmações de Nietzsche sobre os limites e o caráter enganoso da introspecção como meio de autocompreensão (cf. por exemplo A 115, GC 354, ABM 16, 17, 19 e 54, GM I 13, Cl "Razão" 5; cf. ainda Katsafanas 2015, p.119 e pp.126ss., Riccardi 2015a, pp.224ss. e 2015b, pp.541ss.). A partir dessas duas breves observações, dois pontos devem ser destacados: primeiramente, não resta dúvida que, para Nietzsche, como já foi vastamente apontado na literatura secundária, a introspecção é um meio não apenas ineficaz como enganoso de autoconhecimento, e isso especialmente em virtude do fato de que tudo que entra na consciência deve ser formatado segundo esquemas conceituais que falsificam essencialmente o conteúdo daquilo que é experienciado; contudo, o reconhecimento do caráter ilusório do conteúdo da experiência que temos de nós mesmos via introspecção exige, por sua vez, um acesso "introspectivo" (autorreflexivo) à forma segundo a qual essa experiência se dá (isto é, à forma linguístico-predicativa da gramática proposicional) e em virtude da qual ela deve ser vista como cognitivamente inconfiável. Constâncio (2015, p.284) argumenta, nesse sentido, que o ceticismo generalizado de Nietzsche é "não apenas baseado na perspectiva de primeira pessoa - e em particular na perspectiva de primeira pessoa que descobre nosso mundo interior como saturado por construções linguísticas e vazio de conteúdos observacionais puros -, mas esse ceticismo tem também por objetivo lançar dúvidas sobre a abordagem objetiva, de terceira pessoa, com relação ao problema da consciência". Analogamente, num sentido muito próximo à distinção feita acima entre a opacidade do conteúdo da experiência interna e a relativa acessibilidade de sua forma predicativa, Stellino (2015, p.555) argumenta que é preciso distinguir dois sentidos de self (Selbst) no que diz respeito às formulações de Nietzsche acerca do autoconhecimento (selfknowledge, Selbsterkenntnis) e da auto-observação (self-observation, Selbstbeobachtung): num primeiro sentido, o Selbst se referiria ao conteúdo propriamente dito da experiência do mundo interior, cuja natureza íntima nos seria inacessível; num segundo sentido, porém, o Selbst se referiria não ao conteúdo, mas ao modo de funcionamento da mente em suas atividades cognitivas, e esse modo de funcionamento nos seria acessível, ao menos parcialmente, via introspecção, mediante uma correção de certos erros comuns da auto-observação. Baseando-se no fragmento 11[113] de 1887, onde Nietzsche faz nossa noção errônea da mente e de seus processos cognitivos remontar a uma "falsa auto-observação", Stellino sustenta que, neste segundo sentido, o Selbst é o "objeto de uma psicologia genérica cujo objetivo não é decifrar o eu singular de uma pessoa $x$, mas, antes, descobrir os processos universais que regulam certos fenômenos humanos tais como o pensar, o querer, o conhecer, etc." (Stellino 2015, p.555, nota 8). Compartilho dessa leitura de Stellino e acredito que ela encontra suporte também nas seguintes passagens: $N$ 1884, 12[92], N 1885, 38[1] e GC 127. Sobre GC 127 em particular, cf. Dries 2012, p.238. Em seu artigo, Dries procura revalidar a perspectiva de primeira pessoa no contexto das reflexões de Nietzsche sobre a causalidade agencial (agent causation). Teço aqui essas observações com o intuito de dar uma resposta parcial a algumas críticas elaboradas por Riccardi (2014, p.227) ao meu artigo publicado no volume Nietzsches Philosophie des Unbewussten (cf. Mattioli 2012). Uma resposta mais elaborada, abrangendo todos os pontos de sua crítica, ultrapassaria o escopo do presente trabalho. 
Linguagem, pulsão e atavismo: análise genética e mapeamento conceitual ...

a partir da perspectiva daquela unidade sintática da consciência ( $\mathrm{N}$ 1884, 26[432]; 1885, 34[46]). Ela constituiria, dessa forma, uma dimensão pré-predicativa e préreflexiva do nosso "eu” (Selbst), que pretendemos designar através da noção de inconsciente dinâmico-pulsional.

Em oposição ao conceito de consciência da filosofia transcendental, que faz a unidade do pensamento depender estruturalmente da unidade de uma consciência puramente formal, Nietzsche compreende a consciência, nesse contexto, como uma ficção gramatical que exerce um papel funcional para a manutenção da unidade dinâmica do organismo. Por conseguinte, o sujeito transcendental kantiano é reconduzido, como afirma Erwin Schlimgen (1999, p.42), a "um sistema psicológico, biológico e fisiológico de processos dinâmicos. (...) A consciência de si não é o fundamento transcendental da subjetividade, mas sim uma função entre muitas", e que, num nível genético mais originário, está submetida à direção do corpo. Poderíamos, portanto, dizer: não é a consciência formal da apercepção pura, mas sim o corpo que assume aqui o lugar do transcendental.

$\mathrm{Na}$ medida em que entendemos o corpo como este lugar improvável do transcendental, é preciso frisar que sua caracterização não se dá em termos de um vocabulário materialista, mecanicista e/ou fisicalista (Lopes 2011, pp.342ss.). O uso de certas expressões atenuantes ("aparentemente”, “até certo ponto”, “em princípio"), das quais nos servimos acima ao falar da perspectiva de terceira pessoa envolvida no recurso ao corpo como fio condutor da investigação, tinha justamente a intenção de demover eventuais tentações de vincular imediatamente o recurso nietzscheano ao corpo a posições reducionistas e eliminativistas. Nesse sentido, é digno de nota o fato de que a menção à fisiologia ao final do aforismo 20 de Além do bem e do mal, ao reconduzir o argumento à perspectiva de terceira pessoa, ao mesmo tempo desautoriza qualquer interpretação que conceda exclusividade a esta perspectiva e, portanto, qualquer interpretação naturalista no sentido forte (isto é, no sentido de um fisicalismo substantivo e reducionista), ${ }^{23}$ na medida em que fala

23 Lopes (2011, pp.344ss.) argumenta que a melhor forma de compreender o naturalismo de Nietzsche é como um naturalismo metodológico motivado por dois princípios essenciais: a) o cultivo de virtudes epistêmicas necessárias para a boa formação do espírito filosófico, cuja tarefa é fundamentalmente normativa; e b) o princípio pragmático de economia, identificado por ele como algo imposto pela consciência do método, e que exige que não se admita várias espécies de causalidade até que não se tenha levado ao extremo a tentativa de se contentar com uma só (ABM 36). Esse tipo de naturalismo é não apenas ontologicamente mais neutro, como está associado, no contexto geral da obra madura, a uma opção pelo vocabulário intencional (a causalidade da vontade e seu aspecto cognitivo) em detrimento do vocabulário fisicalista. Ao que tudo indica, Nietzsche concede prioridade explicativa ao vocabulário intencional por este ser intuitivamente mais acessível (Lopes 2011, p.346). Isso é válido sobretudo para sua psicofisiologia, mas essa prioridade se estende também à dimensão do mundo físico, como deixa claro a argumentação de ABM 36. Caso essa extensão ultrapasse os limites de uma opção meramente pragmática, motivada pelo critério metodológico da economia de princípios, isso atestaria a adesão de Nietzsche ao pampsiquismo enquanto tese metafísica. Por ultrapassar o escopo do presente artigo, reservo a discussão deste ponto em particular para um outro trabalho. 
em “juízos de valor fisiológicos” (grifo meu). A formulação reinsere imediatamente a perspectiva de primeira pessoa no tratamento do problema, reconhecendo seu caráter incontornável. Nietzsche indica aqui, por uma sutileza na formulação, aquilo que já estava dito mais claramente no aforismo precedente: que o estudo da fisiologia e dos processos orgânicos deve ser situado "no âmbito da moral - moral, entenda-se, como a teoria das relações de dominação sob as quais se origina o fenômeno "vida'” (ABM 19). ${ }^{24}$

Nietzsche pensará o corpo como um sistema dinâmico complexo de interação entre diversos subsistemas pulsionais “inteligentes", e a metáfora da qual ele se vale para a caracterização dessa dinâmica é a metáfora política. A relação entre as diversas pulsões se daria em termos análogos às relações de dominação, isto é, de comando e obediência. A descrição da dimensão volitiva segundo o modelo do comando e da obediência torna clara, dentro desse contexto, a tentativa de traduzir o modo de funcionamento dos impulsos numa linguagem agencial, o que pressupõe um vocabulário essencialmente intencional e mentalista. Os impulsos são descritos como agentes políticos em conflito, capazes de estabelecer alianças, submeter uns aos outros e constituir estruturas sociais organizadas. No aforismo 12 de Além do bem e do mal, encontramos a caracterização da alma, que já não deve mais ser pensada como algo separado do organismo, como uma pluralidade de sujeitos e como uma estrutura social de impulsos e afetos. De acordo com esse modelo, a unidade psíquica é estabelecida mediante a fixação provisória de uma hierarquia entre as diversas pulsões. Essa metáfora política é essencial para a construção da hipótese das vontades de poder, segundo a qual cada impulso deve ser dotado de uma certa capacidade representacional que o torna apto a interagir cognitivamente com outros impulsos, de modo que eles possam, como diz Nietzsche, "conspirar conjuntamente ao poder" (N 1888, 14[186]). É isso que está implicado na tese, vastamente debatida na literatura secundária, segundo a qual toda pulsão percebe, realiza valorações, assume perspectivas e interpreta.

Com esse modelo, Nietzsche se afasta tanto do materialismo cientificista da época quanto do irracionalismo de Schopenhauer. Sua crítica a este último tem por objetivo mostrar que ele substituiu o velho dualismo entre mente e corpo por um novo, o dualismo entre vontade e representação (ou intelecto), que é tão condenável quanto o primeiro (Lopes 2012, p.148). Esse dualismo resulta de um mau uso do

24 Sobre este ponto, ver ainda o importante fragmento 37[4] de 1885 (KSA 11, p.576s.), intitulado "Moral e fisiologia". Ali, Nietzsche fala do corpo, da dependência da unidade da consciência com relação à unidade dinâmica do organismo, e argumenta que o pensar, o sentir e o querer não necessitam, em si mesmos, de nenhum sistema nervoso ou aparato cerebral, sendo processos autônomos pertencentes à dinâmica dos impulsos que, por sua vez, constituem o próprio organismo humano. A comunicação entre esses diversos "seres viventes e intelectos", cuja síntese produz um sistema funcional que dá origem à vida, é, para Nietzsche, "um problema moral, não um problema mecânico!”. 
Linguagem, pulsão e atavismo: análise genética e mapeamento conceitual ...

argumento da analogia, uma vez que, na transposição do sentido psicológico para o sentido metafísico da vontade, Schopenhauer subtraiu sua qualidade intencional, seu direcionamento a um objeto, de modo que a partir daí o que ele chama de vontade não passa de uma "palavra vazia" (N 1888, 14[121]). Trata-se do "equívoco fundamental de Schopenhauer acerca da vontade” (N 1887, 9[169]). Essa crítica, formulada de forma clara nos textos da década de 1880, já se encontra em germe nos apontamentos sobre Schopenhauer escritos entre 1867 e $1868 .^{25}$

Ao apresentar sua famosa fórmula do "corpo como fio condutor" nos escritos da década de 1880 - cuja análise não deve ignorar as reflexões em torno da não menos importante noção de "grande razão do corpo" apresentada no Zaratustra (Z I, Desprezadores) - Nietzsche mantém e elabora aquelas intuições de juventude, desenvolvendo um modelo de compreensão da dinâmica pulsional e uma noção de inconsciente que se afastam significativamente do que é proposto por Schopenhauer. ${ }^{26}$

Podemos dizer que temos aqui duas noções fundamentais de inconsciente em Nietzsche: o inconsciente dinâmico-pulsional, que, enquanto processo corporal, possui um caráter pré-predicativo e pré-reflexivo (mas dotado de intencionalidade), e o inconsciente linguístico-cognitivo de natureza sintático-estrutural, que está sempre envolvido e pressuposto no surgimento da consciência e, dessa forma, atua a priori como pré-condição para toda tradução de processos dinâmicos inconscientes em conteúdos intencionais conscientes. A gramática, portanto, enquanto estrutura axiomática de tudo aquilo que entra na consciência, transmitiria necessidade à experiência, na medida em que a organiza sempre e de forma fixa segundo o esquema

25 Cf. sobre isso Mattioli 2013a, pp.84ss.; Lupo 2006, p.121s., nota 40. Nesses apontamentos de juventude, reunidos sob o título Sobre Schopenhauer, Nietzsche parte da incompatibilidade entre os elementos transcendentais e os elementos naturalistas do sistema schopenhaueriano e aponta para uma solução que, a nosso ver, visa salvaguardar o aspecto transcendental do voluntarismo por meio de um ultrapassamento do idealismo subjetivo ao qual Schopenhauer permanecia vinculado. Isso se dá mediante um deslocamento do transcendental de seu locus subjetivo (encarnado na consciência individual) para o plano transsubjetivo, transpessoal e inconsciente da vontade. Infelizmente não há espaço aqui para uma discussão mais aprofundada deste texto de juventude. Lido mais detalhadamente com esta questão no primeiro capítulo de minha tese de doutorado (cf. Mattioli 2016).

26 Em seu livro Freud e Nietzsche, Assoun (2000, p.82 e p.115) falha em reconhecer este ponto essencial da concepção nietzscheana das pulsões em contraposição a Schopenhauer, isto é, a afirmação do caráter representacional da dinâmica pulsional. Além de filiar Nietzsche prontamente à filosofia schopenhaueriana, Assoun aponta como uma das diferenças mais marcantes entre as concepções do inconsciente de Nietzsche e Freud o fato de que, para Freud, toda atividade pulsional inconsciente está submetida a uma mediação representacional, ao passo que para Nietzsche a representação seria um mero sintoma terminal, próprio à consciência, de um processo puramente orgânico. Ora, de acordo com o que dissemos acima, essa interpretação radicalmente organicista e biologicista está equivocada (cf. por exemplo Abel 2001, em especial p.7. Este artigo seminal, já traduzido no Brasil e publicado no volume Nietzsche na Alemanha (2005), foi republicado em inglês no recém lançado Nietzsche on Mind and Nature (2015, pp.37-56)). Se devemos falar, em Freud, numa necessária "mediação representacional" da dinâmica pulsional, o mesmo deve ser dito com relação a Nietzsche. Gasser, por sua vez, em seu monumental Nietzsche und Freud, reconhece a importância do aspecto intencional na caracterização nietzscheana da pulsão e oferece uma interpretação mais próxima da que sugerimos aqui (Gasser 1997, pp.638ss.). 
sujeito-predicado (Simon 1972, p.11). Por sua vez, as funções dessa gramática, sobre as quais repousa a unidade sintática da consciência, estariam fundadas numa unidade dinâmica que corresponde a um nível geneticamente mais originário, isto é, o nível inconsciente da unidade do organismo, que denominamos acima de inconsciente dinâmico-pulsional. O papel do inconsciente, portanto, tanto em seu aspecto dinâmico-pulsional quanto sintático-estrutural, poderia ser definido como transcendental na medida em que ele está na base de toda constituição subjetiva de mundo, atuando como sua condição de possibilidade, e na medida em que se mostra como instância explicativa não acessível direta e integralmente à introspecção, mas cuja descrição escapa ao vocabulário meramente empirista ou fisicalista, exigindo um apelo à perspectiva de primeira pessoa, ao vocabulário intencional e a uma abordagem cognitivista.

\section{Referências}

Abel, G. (2001). Bewußtsein - Sprache - Natur. Nietzsches Philosophie des Geistes. Nietzsche-Studien, 30, pp.1-43.

Adler, H. (1988). Fundus animae - der Grund der Seele. Zur Gnoseologie des Dunklen in der Aufklärung. Deutsche Vierteljahrschrift für Literatur und Geistesgeschichte, 62, pp.197-220.

Anderson, L. (2002). Sensualism and Unconscious Representations in Nietzsche's Account of Knowledge. International Studies in Philosophy, 34(3), pp.95-117.

Assoun, P. L. (2000). Freud and Nietzsche. Translated by Richard L. Collier, Jr. London / New York: Continuum.

Baas, B. (2001). Freud, a realidade psíquica e a tentação do transcendental. Tradução de Gérard Grimberg e Angélica Bastos. Ágora: Estudos em Teoria Psicanalítica, $4(2)$, pp.9-23.

Bishop, P. (1995). Jung's Annotations of Nietzsche's Works: An Analysis. NietzscheStudien, 24, pp.271-314.

Brinkmann, D. (1943). Probleme des Unbewußten. Rascher Verlag: Zürich / München.

Cavalcanti, A. H. (2005). Símbolo e Alegoria: a gênese da concepção de linguagem em Nietzsche. São Paulo/Rio de Janeiro: Annablume/Fapesp/DAAD.

Constâncio, J. (2015). Nietzsche on Decentered Subjectivity or, the Existential Crisis of the Modern Subject. In: Constâncio, J., Branco M. J. M., Ryan, B. (Org.). Nietzsche and the Problem of Subjectivity. Berlin/Boston: Walter de Gruyter.

Crawford, C. (1988). The Beginnings of Nietzsche's Theory of Language. Berlin/ /New York: Walter de Gruyter.

D’lorio, P. (1993). La superstition des philosophes critiques. Nietzsche et Afrikan Spir. Nietzsche-Studien, 22, pp.257-294.

Drawin, C. (2005). O paradoxo da finitude: sobre sentido onto-antropológico da 
psicanálise freudiana. (Tese de doutorado). Faculdade de Filosofia e Ciências Humanas. UFMG: Belo Horizonte.

Dries, M. (2012). The Feeling of Doing - Nietzsche on Agent Causation. Nietzscheforschung, 20, pp.235-247.

Eisler, R. (1961). Kant-Lexikon. Nachschlagewerk zu Kants sämtlichen Schriften, Briefen und handschriftlichem Nachlass. Unveränderte reprograf. Nachdruck der Ausgabe Berlin 1930. Hildesheim: Olms.

Emden, C. (2014). Nietzsche's Naturalism. Philosophy and the Life Sciences in the Nineteenth Century. Cambridge: Cambridge University Press.

Frezzatti Jr., W. (2014). Nietzsche contra Darwin. 2. edição ampliada e revista. São Paulo: Edições Loyola.

Freud, S. (1941-1968). Gesammelte Werke (GW). Chronologisch geordnet. 18 Bände. Frankfurt am Main / London: S. Fischer Verlag / Imago Publishing.

. (2010). "O inconsciente". In: Obras completas, volume 12. Introdução ao narcisismo, Ensaios de metapsicologia e outros textos (1914-1916). Tradução de Paulo César de Souza. São Paulo: Companhia das letras.

. (2010). História de uma neurose infantil. In: Obras completas, volume 14. História de uma neurose infantil ("O homem dos lobos"), Além do princípio do prazer e outros textos (1917-1920). Tradução de Paulo César de Souza. São Paulo: Companhia das letras.

- (2010). Uma dificuldade da psicanálise. In: Obras completas, volume 14. História de uma neurose infantil ("O homem dos lobos"), Além do princípio do prazer e outros textos (1917-1920). Tradução de Paulo César de Souza. São Paulo: Companhia das letras.

Gardner, S. (1999). Schopenhauer, Will, and the Unconscious. In: Janaway, C. (Org.) The Cambridge Companion to Schopenhauer. Cambridge: Cambridge University Press.

Gasser, R. (1997). Nietzsche und Freud. Berlin / New York: Walter de Gruyter.

Giacoia Jr., O. (2011). Metafísica e subjetividade. In: Martins, A., Santiago, H., Oliva, L. C. (Org.). As ilusões do eu: Spinoza e Nietzsche. Rio de Janeiro: Civilização Brasileira.

Gödde, G. (2009). Traditionslinien des „Unbewußten“. Schopenhauer - Nietzsche Freud. Gießen: Psychosozial-Verlag.

Grau, K. J. (1916). Die Entwicklung des Bewusstseinsbegriffes im XVII und XVIII Jahrhundert. Halle: Max Niemeyer Verlag.

. (1922). Bewusstsein, Unbewusstes, Unterbewusstes. München: Rösl.

Hartmann, E. von. (1869). Philosophiedes Unbewußten. Versucheiner Weltanschauung. Berlin: Carl Duncker's Verlag.

Helmholtz, H. von. (1855). Ueber das Sehen des Menschen. Ein populärer wissenschaftlicher Vortrag. Leipzig: Leopold Voss. 
Itaparica, A. (2011). Crítica à modernidade e conceito de subjetividade em Nietzsche. Estudos Nietzsche, 2(1), pp.59-78.

Kant, I. Kants gesammelte Schriften. Akademie-Ausgabe = AA. Berlin/Leipzig: Walter de Gruyter. [Versão online]. Recuperado de http://www.korpora.org/kant. Acesso em 15/12/2016.

. (2001). Crítica da razão pura (CRP). Tradução de Manuela Pinto dos Santos e Alexandre Fradique Morujão. Lisboa: Fundação Calouste Gulbenkian.

Katsafanas, P. (2005). Nietzsche's Theory of Mind: Consciousness and Conceptualization. European Journal of Philosophy, 13 (1), pp.1-31.

. (2015). Kant and Nietzsche on Self-Knowledge. In: Constâncio, J., Branco, M. J. M., Ryan, B. (orgs.). Nietzsche and the Problem of Subjectivity. Berlin/Boston: Walter de Gruyter.

Kemp Smith, N. (2003). A Comentary to Kant's Critique of Pure Reason. 3. edição. New York: Palgrave MacMillan.

La Rocca, C. (2008). "Der dunkle Verstand. Unbewusste Vorstellungen und Selbstbewusstsein bei Kant" In: Rohden, V., Terra, R., Almeida, G. de e Ruffing, M. (Org..). Law and Peace in Kant's Philosophy / Recht und Frieden in der Philosophie Kants. Akten des X. Internationalen Kant-Kongresses (pp.458-468). Berlin / New York: Walter de Gruyter.

Liebmann, O. (1911). Die Metamorphosen des Apriori. In Zur Analysis der Wirklichkeit. Philosophische Untersuchungen. Strassburg: Karl J. Trübner.

Lopes, R. (2006). Elementos de retórica em Nietzsche. Edições Loyola: São Paulo.

(2011). “A ambicionada assimilação do materialismo": Nietzsche e o debate naturalista na filosofia alemã da segunda metade do século XIX. Cadernos Nietzsche, 29. São Paulo, pp.309-352.

- (2012). Das politische Triebmodell Nietzsches als Gegenmodell zu Schopenhauers Metaphysik des Willens. In: Georg, J. e Zittel, K. (Org.) Nietzsches Philosophie des Unbewussten. Berlin / Boston: Walter de Gruyter.

Loukidelis, N. (2006). Nachweis aus Otto Liebmann, Zur Analysis der Wirklichkeit. Nietzsche-Studien, 35, 2006, pp.302-303.

(2013). „Es denkt“. Ein Kommentar zum Aphorismus 17 aus Jenseits von Gut und Böse. Würzburg: Königshausen \& Neumann.

Lupo, L. (2006). Le colombe dello scetico. Riflessioni di Nietzsche sulla conscienza negli anni 1880-1888. Pisa: Edizioni ETS.

Mattioli, W. (2010). Metáfora e ficcionalismo no jovem Nietzsche. Revista Trágica, 3 (2), pp.39-60. Recuperado de http://tragica.org/artigos/v3n2/william.pdf. Acesso em 16.12.2016.

. (2012). Das Unbewusste als transzendentaler Raum perspektivistischer Weltbildung bei Nietzsche. In: Georg, J. e Zittel, K. (orgs. ). Nietzsches Philosophie des Unbewussten. Berlin / Boston: Walter de Gruyter. 
(2013a). Inconsciente, intencionalidade e natureza: a dialética morganática entre naturalismo e transcendentalismo na metafísica da vontade de Schopenhauer. Revista Voluntas: Estudos sobre Schopenhauer, 4 (1), pp.66-97.

- (2013b). O devir e o lugar da filosofia: alguns aspectos da recepção e da crítica de Nietzsche ao idealismo transcendental via Afrikan Spir. Kriterion: Revista de Filosofia, 128, pp.321-348.

(2016) $O$ inconsciente no jovem Nietzsche. Da intencionalidade das formas naturais à vida da linguagem. (Tese de doutorado). Faculdade de Filosofia e Ciências Humanas. UFMG: Belo Horizonte.

Moore, G. (2003). Nietzsche, Biology and Metaphor. Cambridge: Cambridge University Press.

Nicholls, A. e Liebscher, M. (2010). “Introduction”. In: (orgs.). Thinking the Unconscious. Nineteenth-Century German Thought. Cambridge University Press.

Nietzsche, F. W. (1999). Sämtliche Werke. Kritische Studienausgabe (KSA). Herausgegeben von Giorgio Colli und Mazzino Montinari. 15 Bände. Berlin: Walter de Gruyter.

. (1995). Werke. Kritische Gesamtausgabe (KGW). Herausgegeben von Giorgio Colli und Mazzino Montinari. Berlin. New York: Walter de Gruyter.

- (2011). Sobre verdade e mentira no sentido extramoral. Tradução de Fernando de Moraes Barros. São Paulo: Hedra.

- (2005). Humano, demasiado humano. Tradução de Paulo César de Souza. São Paulo: Companhia das Letras.

- (2001). A Gaia Ciência. Tradução de Paulo César de Souza. São Paulo: Companhia das Letras.

- (2005). Além do Bem e do Mal: Prelúdio a uma Filosofia do Futuro. Tradução de Paulo César de Souza. São Paulo: Companhia das Letras.

- (2006). Crepúsculo dos ídolos. Tradução de Paulo César de Souza. São Paulo: Companhia das Letras.

Orsucci, A. (1994). Unbewußte Schlüsse, Antecipationen, Übertragungen. Über Nietzsches Verhältnis zu Karl Friedrich Zöllner und Gustav Gerber. In: Borsche, T., Gerratana, F., Venturelli, A. (Org.). Centauren-Geburten: Wissenschaft, Kunst und Philosophie beim jungen Nietzsche. Berlin/New York: Walter de Gruyter.

. (1996). Orient - Okzident. Nietzsches Versuch einer Loslösung vom europäischen Weltbild. Berlin / New York: de Gruyter.

Reuter, S. (2004). Reiz. Bild. Unbewusste Anschauung. Nietzsches Auseinandersetzung mit Hermann Helmholtz' Theorie der unbewussten Schlüsse in Über Wahrheit und Lüge im aussermoralischen Sinne. Nietzsche-Studien, 33, pp.351-372.

(2009). An der „Begräbnissstätte der Anschauung“. Nietzsches Bildund Wahrnehmungstheorie in Ueber Wahrheit und Lüge im aussermoralischen Sinne. Basel: Schwabe. 
Rhoden, V. (2009). Representações não-conscientes em Kant. Revista AdVerbum, $4(1), \mathrm{pp} .3-9$.

Riccardi, M. (2009). „Der faule Fleck des Kantischen Kriticismus“. Erscheinung und Ding an sich bei Nietzsche. Basel: Schwabe.

- (2014). [Resenha de Nietzsches Philosophie des Unbewussten, organizado por Jutta Georg e Claus Zittel]. The Journal of Nietzsche Studies, 41 (2), pp.225-227.

- (2015a). Inner Opacity. Nietzsche on Introspection and Agency. Inquiry: An Interdisciplinary Journal of Philosophy, 58 (3), pp.221-243.

. (2015b). Nietzsche on the Embodiment of Mind and Self. In: Constâncio, J., Branco, M. J. M., Ryan, B. (orgs.). Nietzsche and the Problem of Subjectivity. Berlin/Boston: Walter de Gruyter.

Satura, V. (1971). Kants Erkenntnispsychologie in den Nachschriften seiner Vorlesungen über empirische Psychologie. Bonn: Bouvier Verlag Herbert Grundmann.

Schlimgen, E. (1999). Nietzsches Theorie des Bewußtseins. Berlin/New York: Walter de Gruyter.

Simon, J. (1972). Grammatik und Wahrheit. Über das Verhältnis Nietzsches zur spekulativen Satzgrammatik der metaphysischen Tradition. Nietzsche-Studien, 1, pp.1-26.

(1984). Das Problem des Bewußtseins bei Nietzsche und der traditionelle Bewußtseinsbegriff. In: Djuriae, M. e Simon, J. (orgs.). Zur Aktualität Nietzsches, Volume II. Würzburg: Königshausen \& Neumann, pp.17-33.

Souza, L. e Brito, A. (2015). As representações sem consciência em Kant. Pensando Revista de Filosofia, 6 (11), pp.292-326.

Stack, G. (1983). Lange and Nietzsche. Berlin. New York: Walter de Gruyter.

Stellino, P. (2015). Self-Knowledge, Genealogy, Evolution. In: Constâncio, J., Branco M. J. M., Ryan, B. (orgs.). Nietzsche and the Problem of Subjectivity. Berlin/ Boston: Walter de Gruyter.

Recebido em: 11.01.2017

Aceito em: 06.06.2017 